\title{
Potensi Daun Trembilungan (Begonia hirtella Link) sebagai Antibakteri dan Antifungi
}

\author{
Febri Nur Ngazizah ${ }^{1}$, Nuraeni Ekowati ${ }^{1}$, Aisyah Tri Septiana ${ }^{2}$ \\ ${ }^{1}$ Fakultas Biologi, Universitas Jenderal Soedirman \\ ${ }^{2}$ Fakultas Pertanian, Universitas Jenderal Soedirman \\ Email : nuraeniekowati@yahoo.com
}

\begin{abstract}
Begonia hirtella leaf are commonly used by people in mountainous areas to treat itchy due to insect bites and skin infection. This study aims to (1) determine proper solvent extract of $B$. hirtella leaf on antibacterial activity of $S$. aureus and $E$. coli and on antifungal activity of $C$. albicans (2) determine the lowest concentration of leaf extract of $B$. hirtella that indicate the formation of inhibition zone (3) know the content of bioactive compounds contained in each leaf extract of $B$. hirtella. The method used in this study is experimental with completely randomized design (CRD). The treatments were type of solvents ( $n$-hexane, ethyl acetate, ethanol and water) and a serie of the ethyl acetate extract concentration of 500 ppm, 450 ppm, 400 ppm, 350 ppm, 300 ppm and 250 ppm against S. aureus, E. coli and C. albicans. Data were analyzed using analysis of variance (Anova) and the significant differences between the treatments were analyzed by Duncan test at $95 \%$ confidence level. The result showed that each solvent extracts affect microbes growth with a highly significant difference $\mathrm{p}<0.05$. Solvent extracts that have the best inhibitory zone is ethyl acetate against $S$. aureus with an average diameter of inhibitory zone $13.75 \pm 1.26 \mathrm{~mm}$. Increasing concentrations of ethyl acetate extract of $250 \mathrm{ppm}$ to $500 \mathrm{ppm}$ increase inhibition zone against microbes. The lowest concentration that show inhibition zone was $300 \mathrm{ppm}$. The formation inhibition of zone on microbes growth happened due to their compounds in the extract. Extract of $n$-hexane contains stigmasterol, ethyl acetate contains neophytadiene, while the ethanol extract contains ethyl palmitate.
\end{abstract}

Keywords: Antibacterial, Antifungal, Begonia hirtella, inhibition zone, bioactive compounds.

\section{Abstrak}

Daun Begonia hirtella biasa digunakan masyarakat di daerah pegunungan untuk mengobati gatal karena digigit serangga dan gatal karena infeksi kulit. Penelitian ini bertujuan untuk (1) mengetahui jenis pelarut ekstrak daun $B$. hirtella terbaik terhadap aktivitas antibakteri $S$. aureus dan $E$. coli serta antifungi $C$. albicans (2) mengetahui konsentrasi ekstrak daun $B$. hirtella minimal yang menunjukkan terbentuknya zona hambat (3) mengetahui kandungan senyawa bioaktif yang terdapat pada masing-masing ekstrak daun $B$. hirtella. Metode yang digunakan dalam penelitian ini adalah eksperimental dengan Rancangan Acak Lengkap (RAL). Perlakuan yang dicobakan adalah jenis pelarut ( $n$-heksan, etil asetat, etanol dan air) dan variasi konsentrasi ekstrak etil asetat $500 \mathrm{ppm}, 450$ ppm, 400 ppm, 350 ppm, 300 ppm dan 250 ppm terhadap S. aureus, E. coli dan C. albicans. Data yang diperoleh dianalisis menggunakan analisis ragam (Anova) dan perbedaan nyata antara perlakuan dianalisis dengan uji Duncan pada tingkat kepercayaan $95 \%$. Hasil penelitian menunjukkan bahwa masing-masing pelarut ekstrak berpengaruh terhadap mikroba uji dengan perbedaan yang nyata $p<0,05$. Pelarut ekstrak yang mempunyai zona hambat terbaik adalah etil asetat terhadap $S$. aureus dengan diameter rata-rata zona hambat 13,75 $\pm 1,26 \mathrm{~mm}$. Peningkatan konsentrasi ekstrak etil asetat 250 ppm sampai 500 ppm meningkatkan zona hambat terhadap mikroba uji. Konsentrasi minimal yang menunjukkan zona hambat adalah $300 \mathrm{ppm}$. Terbentuknya zona hambat pada mikroba uji disebabkan adanya kandungan senyawa pada ekstrak yang digunakan. Ekstrak $n$-heksan mengandung stigmasterol, ekstrak etil asetat mengandung neophytadiene, sedangkan pada ekstrak etanol mengandung ethyl palmitate.

Kata kunci: Antibakteri, Antifungi, Begonia hirtella, zona hambat, senyawa bioaktif.

\section{Pendahuluan}

Tanaman berkhasiat obat adalah jenis tanaman yang pada bagian bagian tertentu baik akar, batang, kulit, daun, maupun hasil ekskresinya dipercaya dapat menyembuhkan atau mengurangi rasa sakit. Salah satu tanaman berkhasiat yang tumbuh subur di Indonesia adalah tanaman Begonia. Begonia dapat digunakan sebagai obat gatal karena digigit serangga dan infeksi kulit. Penelitian yang dilakukan oleh Hartutiningsih et al., (2009) dan Indrakumar et al. (2014) menunjukkan Begonia mempunyai potensi sebagai antibakteri terhadap bakteri Staphylococcus aureus dan Escherichia coli. Hasil uji fitokimia menunjukkan bahwa tanaman tersebut mengandung senyawa golongan fenol, flavanoid, steroid, terpenoid dan alkaloid.

Salah satu spesies Begonia yang dimanfaatkan masyarakat sebagai obat adalah Begonia hirtella. Pemanfaatan tanaman tersebut karena adanya kandungan senyawa bioaktif yang berperan dalam penyembuhan penyakit tertentu. Seperti pada tanaman lain pada umumnya, senyawa-senyawa tersebut dapat diperoleh dengan cara ekstraksi atau isolasi dengan pelarut non polar ( $n$-heksan), semi polar (etil asetat) dan polar (etanol dan air). Pelarut umum yang sering 
digunakan dalam ekstraksi adalah etanol, karena pelarut tersebut dapat menarik senyawa non polar, semi polar maupun polar (Nagariya et al., 2010; Harborne, 1987).

Ekstraksi senyawa bioaktif dapat dilakukan dengan metode maserasi secara bertingkat dimulai dari pelarut non polar kemudian diikuti semi polar dan polar. Maserasi tersebut dimaksudkan untuk menyaring senyawa non polar seperti steroid dan terpenoid, senyawa semipolar seperti senyawa fenol dan flavanoid serta senyawa polar seperti flavanoid dan alkaloid.

Jenis senyawa dalam ekstrak tanaman $B$. hirtella dapat diketahui malalui identifikasi menggunakan pereaksi warna secara kualitatif, gas chromatography mass spectrometer (GCMS) secara kualitatif dan kuantitatif, di samping itu uji total fenol secara kuantitatif dengan spektrofotometri dilakukan untuk mengetahui kadarnya. Selanjutnya dilakukan uji aktivitas terhadap bakteri Gram positif (S. aureus), Gram negatif ( $E$. colli), dan fungi (Candida albicans).

Penelitian ini bertujuan untuk mengetahui pelarut ekstrak yang memberikan aktivitas maksimal sebagai antibakteri S. aureus, E. coli serta antifungi $C$. albicans, mengetahui konsentrasi ekstrak daun $B$. hirtella minimal yang menunjukkan terbentuknya zona hambat dan mengetahui kandungan senyawa bioaktif yang terdapat pada masing-masing ekstrak daun $B$. hirtella

\section{Metode}

Penelitian ini menggunakan daun $B$. hirtella yang diekstrak dengan pelarut $n$-heksan, etil asetat, etanol dan air. Penelitian dilakukan secara eksperimental, rancangan percobaan yang digunakan adalah Rancangan Acak Lengkap (RAL), dengan perlakuan uji daya hambat menggunakan ekstrak $n$-heksan, etil asetat, etanol dan air terhadap $S$. aureus, E. coli dan $C$. albicans, dengan 4 kali ulangan. Ekstrak yang mempunyai zona hambat terbesar selanjutnya dilakukan uji lanjut dengan perlakuan variasi konsentrasi (500 ppm, 450 ppm, 400 ppm, 350 ppm, 300 ppm dan 250 ppm) terhadap $S$. aureus, $E$. coli dan C. albicans, dengan 3 kali ulangan. Parameter yang diukur adalah zona hambat yang terbentuk.

\section{Ekstraksi (Hartutiningsih et al., 2009; Widyawati et al., 2010)}

Metode yang digunakan dalam pembuatan ekstrak daun tanaman $B$. hirtella adalah metode maserasi. Pelarut yang digunakan adalah $n$ heksan, etil asetat, etanol dan air. Serbuk kering daun direndam selama 24 jam dengan menggunakan pelarut $n$-heksan dengan perbandingan 200 gram serbuk daun: $674 \mathrm{ml}$ pelarut, setelah 24 jam disaring dengan menggunakan kertas saring, ampas direndam kembali menggunakan pelarut $n$-heksan selama 24 jam, disaring lagi, (ekstraksi dilakukan 3x). Hasil penyaringan dikumpulkan menjadi satu dimasukkan ke dalam labu Erlenmeyer sedangkan ampas (daun B. hirtella) dikeringkan sampai tidak berbau $n$-heksan, kemudian direndam ke dalam pelarut etil asetat selama $3 \times 24$ jam, setiap 24 jam disaring dan hasil saringan dimasukkan ke dalam labu Erlenmeyer. Ampas hasil maserasi etil asetat dikeringkan selanjutnya direndam dengan menggunakan pelarut etanol dengan perbandingan dan lama perendaman sama seperti pada maserasi menggunakan pelarut etil asetat, demikian pula pada maserasi ke empat dengan menggunakan pelarut air. Ekstrak yang dihasilkan dipisahkan dengan pelarut dengan cara diuapkan dengan menggunakan alat rotary evaporator sampai dihasilkan ekstrak kental.

\section{Uji aktivitas antibakteri dan antifungi (Efendi dan Hertiani, 2013)}

Sebanyak $10 \mathrm{ml}$ media NA untuk bakteri, sedangkan untuk fungi digunakan media PDA dimasukkan ke dalam cawan petri kemudian dimasukkan $100 \mu \mathrm{L}$ mikroba, mikroba tersebut diratakan dengan drugalsky. Ekstrak ( $n$-heksan, etil asetat, etanol dan air) diteteskan sebanyak 50 $\mu \mathrm{l}$ dengan konsentrasi 1000 ppm pada masingmasing kertas cakram, kemudian kertas cakram tersebut diletakkan di atas media agar. Setelah didiamkan selama 30 menit, cawan diinkubasi pada suhu $37^{\circ} \mathrm{C}$ selama $16-18$ jam. Adanya daerah bening di sekeliling cakram kertas menunjukkan adanya aktivitas antibakteri dan antifungi. Zona bening tersebut diukur diameternya menggunakan penggaris.

\section{Uji aktivitas antibakteri dan antifungi berbagai variasi konsentrasi pelarut terbaik}

Sama halnya dengan uji aktivitas antibakteri dan antifungi pada berbagai pelarut, hanya saja ekstrak yang diteteskan ke dalam kertas cakram adalah ekstrak yang berupa variasi konsentrasi pelarut dengan zona hambat paling besar. Variasi konsentrasi yang digunakan yaitu 500 ppm, 450 ppm, 400 ppm, 350 ppm, 300 ppm dan 250 ppm.

\section{Uji kandungan senyawa menggunakan pereaksi warna}

Meliputi uji Saponin,tannin dan terpenoid.

Analisis total fenol (Andarwulan dan Shetty, 1999)

Dibuat seri larutan standar asam tanat dalam etanol yang digunakan sebagai kurva standar. Pembuatan standar asam tanat yaitu melarutkan asam tanat dalam etanol $95 \%$, kemudian dibuat seri pengenceran $0 \mathrm{ppm}, 25 \mathrm{ppm}, 50 \mathrm{ppm}, 75$ ppm, $100 \mathrm{ppm}$, dan $125 \mathrm{ppm}$. Untuk analisis sampel, diambil $1 \mathrm{ml}$ sampel dari masing-masing 
pengenceran dan dimasukkan ke dalam tabung reaksi bersih. Ditambah $1 \mathrm{ml}$ etanol 95\%, $5 \mathrm{ml}$ air bebas ion dan $0,5 \mathrm{ml}$ reagen folin ciocalteau $50 \%$ pada masing-masing tabung reaksi. Divortex dan didiamkan selama 5 menit. Setelah 5 menit ditambah $1 \mathrm{ml}$ larutan $\mathrm{Na}_{2} \mathrm{CO}_{3} 5 \%$, kemudian divortex dan disimpan pada tempat gelap selama 60 menit. Setelah diinkubasi pada tempat gelap, sampel divortex kembali dan diukur absorbansinya pada panjang gelombang $725 \mathrm{~nm}$. Kadar fenolik dalam masing-masing ekstrak dihitung dengan memasukkan absorbansi sebagai Y dalam kurva baku, sehingga diketahui kadar fenol total dalam ekstrak uji (X)

\section{Analisis dengan GC-MS}

Alat ini digunakan untuk mengetahui jenis dan kadar senyawa bioaktif dari ekstrak daun $B$. hirtella.

\section{Analisis data}

Kandungan senyawa dan total fenol dianalisis secara deskriptif, sedangkan data aktivitas antibakteri dan antifungi dianalisis menggunakan analisis ragam (Anova), dilanjutkan dengan uji Duncan pada tingkat kepercayaan 95\%.

\section{Hasil dan Pembahasan}

\section{Uji Kandungan Senyawa bioaktif ekstrak daun B. hirtella}

Uji kandungan senyawa bioaktif dilakukan secara kualitatif dengan pereaksi warna, dan GCMS. Di samping itu juga ditentukan kadar total fenol. Hasil uji golongan senyawa pada ekstrak dengan pelarut yang berbeda memberikan hasil senyawa yang berbeda pula. Hal ini karena senyawa bioaktif pada tanaman akan terlarut pada pelarut yang mempunyai tingkat kepolaran yang sama dengan senyawa tersebut. Menurut Himawan et al. (2012) didasarkan pada prinsip like dissolves like bahwa senyawa yang bersifat polar akan mudah larut dalam pelarut polar, sedangkan senyawa nonpolar akan mudah larut dalam pelarut nonpolar.

Hasil pengamatan kandungan senyawa dengan pereaksi warna diketahui bahwa ekstrak etil asetat, ekstrak etanol dan ekstrak air positif mengandung senyawa saponin. Hal ini sesuai dengan pernyataan Darsana et al. (2012) bahwa saponin merupakan glukosida yang larut dalam pelarut polar. Reaksi Saponin positif ditandai dengan terbentuknya busa. Menurut Marliana et al. (2005), apabila terbentuk busa yang mantap (tidak hilang selama 30 detik) maka menunjukkan adanya saponin.

Ekstrak $n$-heksan, etanol dan air, positif mengandung alkaloid, yang ditandai adanya endapan merah setelah penambahan pereaksi Dragendorff. Nagariya et al. (2010) menyatakan pada reaksi menggunakan reagen Dragendorf, dinyatakan bahwa ion logam $\mathrm{K}^{+}$membentuk ikatan kovalen dengan alkaloid sehingga membentuk kompleks kalium-alkaloid yang mengendap.

Senyawa tanin bersifat polar sehingga dari hasil uji tanin yang positif hanya pada ekstrak etanol dan ekstrak air yang ditandai dengan terbentuknya warna hijau kehitaman setelah ekstrak diberi larutan $\mathrm{FeCl}_{3}$. Sangi et al. (2008) menyatakan tanin dibagi menjadi dua golongan dan masing-masing golongan memberikan reaksi warna yang berbeda terhadap $\mathrm{FeCl}_{3} 1 \%$. Golongan tanin hidrolisis akan menghasilkan warna biru kehitaman dan tanin kondensasi akan menghasilkan warna hijau kehitaman. Reaksi antara $\mathrm{FeC}_{3}$ bereaksi dengan salah satu gugus hidroksil yang ada pada senyawa tanin akan menimbulkan warna. Ekstrak yang positif mengandung terpenoid adalah ekstrak $n$-heksan dan ekstrak etil asetat, kedua ekstrak tersebut berwarna merah setelah diberi pereaksi Lieberman Buchard.

Selain dengan uji fitokimia, untuk mengetahui kandungan senyawa dilakukan dengan menghitung kadar total fenol. Hasil uji kadar total fenol tersebut menunjukkan golongan senyawa fenol lebih banyak terekstrak pada pelarut polar dibandingkan pelarut semipolar dan non polar. Menurut Rafsanjani dan Putri (2015) hasil tersebut disebabkan komponen fenolik yang bersifat semipolar mudah terekstrak oleh etil asetat yang mempunyai konstanta dielektrik 6,02 sedangkan komponen yang polar mudah terekstrak oleh etanol konstanta dielektrik 24,30. Hal ini menunjukkan bahwa golongan senyawa fenol pada daun $B$. hirtella lebih banyak yang bersifat polar.

Jenis senyawa dalam ekstrak telah diketahui dengan uji GCMS. Ekstrak n-heksan mengandung stigmasterol, campesterol, squalene, gamma sitosterol dan alpha ergosterol. Pada ekstrak etil asetat teridentifikasi neophytadiene, stigmasterol, squalene, palmitinic acid dan gamma sitosterol. Sedangkan pada ekstrak etanol mengandung senyawa antara lain ethyl palmitate, palmitic acid, ethyl linolenat dan acetol.

\section{Uji Antibakteri dan Antifungi}

Uji Antibakteri dan antifungi dilakukan untuk mengetahui pengaruh daun $B$. hirtella yang diekstrak dengan pelarut $n$-heksan, etil asetat, etanol dan air terhadap zona hambat $E$. coli, $S$. aureus dan $C$. albicans menggunakan metode difusi agar Kirby Bauer. Pengujian menggunakan kertas cakram berdiameter $6 \mathrm{~mm}$ yang telah disterilkan terlebih dahulu. Pada kertas cakram tersebut diteteskan ekstrak sebanyak $50 \mu \mathrm{L}$. Zona hambat yang terbentuk ditandai adanya daerah bening di sekeliling cakram, besarnya zona hambat diketahui dengan pengukuran diameter daerah bening tersebut. Zona hambat pada $S$. 
aureus dari yang terbesar hingga terkecil yaitu ekstrak etil asetat, ekstrak air, ekstrak etanol dan ekstrak $n$-heksan. Sedangkan pada E. coli yaitu ekstrak etil asetat, ekstrak air, ekstrak $n$-heksan dan ekstrak etanol. Berbeda dengan $S$. aureus dan E. Coli, zona hambat pada C. albican terbesar pada ekstrak etil asetat kemudian disusul dengan ekstrak $n$-heksan, ekstrak etanol dan ekstrak air (Gambar 1).
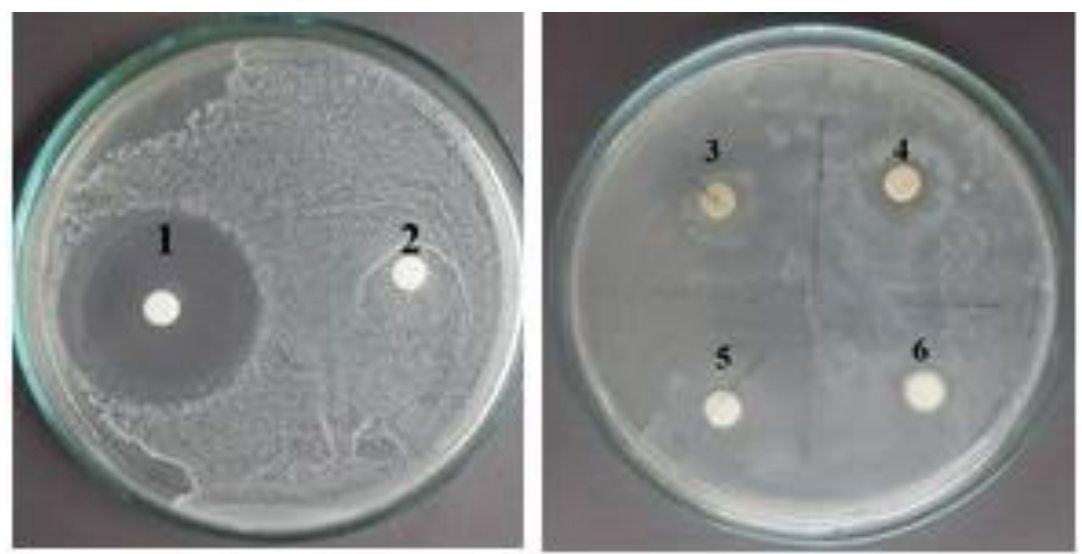

(A)
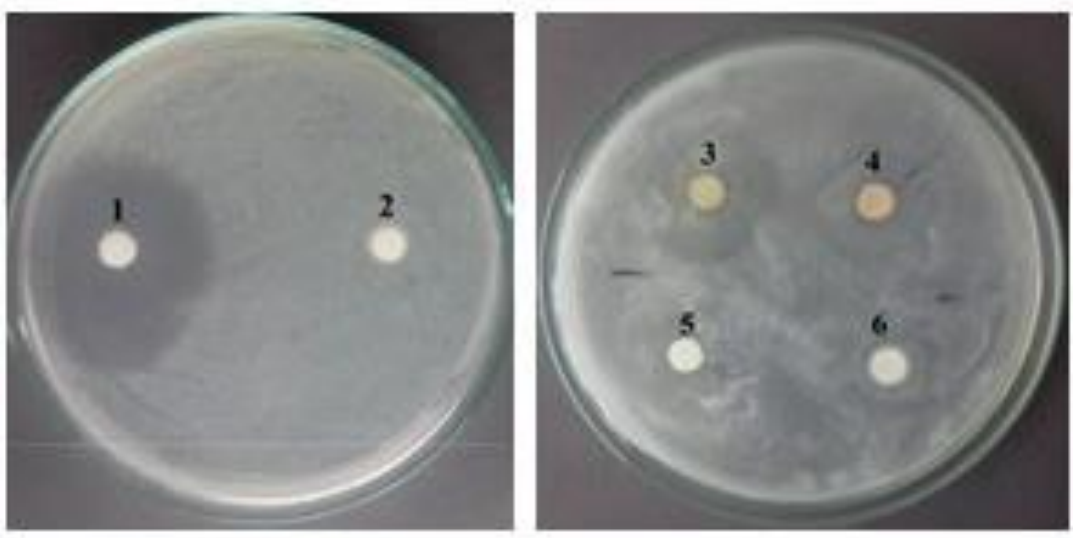

(B)
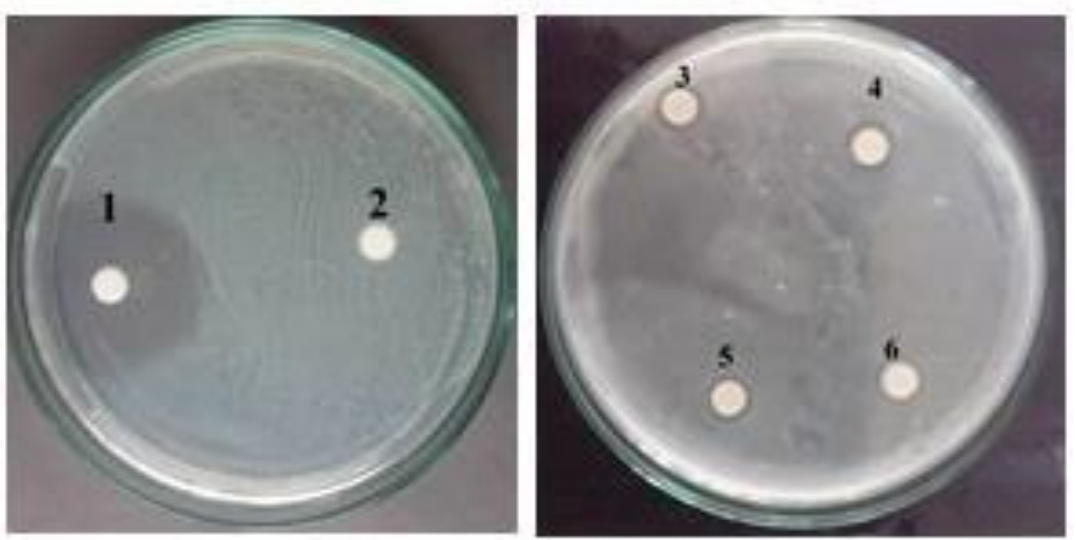

(C)

Gambar 1. Zona hambat pada uji antimikroba A. S. aureus, B. E. coli, C. C. albicans, 1. kontrol positif, 2. kontrol negatif, 3. ekstrak $n$-heksan, 4. ekstrak etil asetat, 5. ekstrak etanol dan 6. ekstrak air

Kontrol positif yang digunakan untuk bakteri adalah kloramfenikol. Kloramfenikol berfungsi sebagai pembanding karena merupakan jenis antibiotik yang memiliki spektrum luas terhadap bakteri Gram positif dan Gram negatif.
Kloramfenikol menunjukkan zona hambat terhadap mikroba uji.

Nilai rata-rata zona hambat pada mikroba uji disajikan pada Gambar 2. Gambar 2. Menunjukkan bahwa kloramfenikol dan perlakuan ekstrak 
membentuk zona hambat. Zona hambat pada kloramfenikol tergolong zona hambat yang sangat kuat. Menurut Davis dan Stout (1971), ketentuan daya antibiotik yaitu daerah hambatan $20 \mathrm{~mm}$ atau lebih termasuk kategori sangat kuat, daerah hambatan 10-20 $\mathrm{mm}$ kategori kuat, daerah hambatan 5-10 $\mathrm{mm}$ kategori sedang dan daerah hambatan $\leq 5 \mathrm{~mm}$ kategori lemah. Perlakuan ekstrak daun $B$. hirtella juga membentuk zona hambat dengan spektrum luas sebagai antibakteri yang ditandai dengan terbentuknya zona hambat pada bakteri uji. Zona hambat pada kontrol positif dan perlakuan ekstrak bakteri uji tersaji pada gambar di bawah ini :

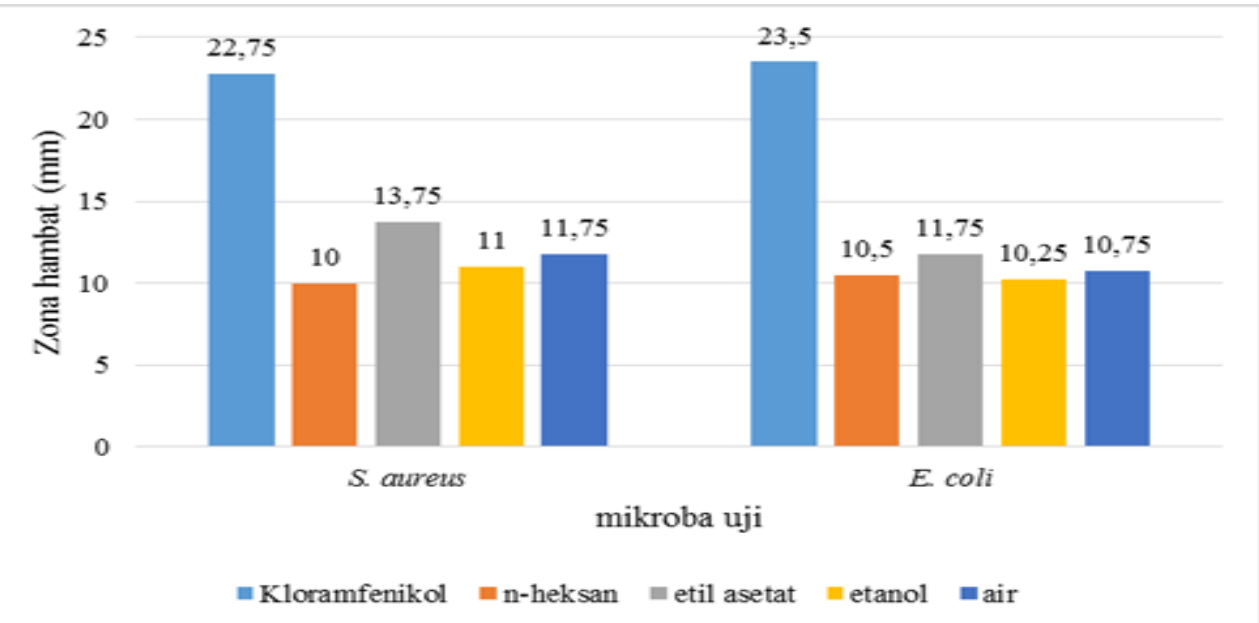

Gambar 2. Rata-rata zona hambat pada mikroba S. aureus dan E. coli dengan perlakuan kloramfenikol, ekstrak $n$-heksan, ekstrak etil asetat, ekstrak etanol dan ekstrak air.

Besarnya zona hambat pada uji aktivitas antimikroba menunjukkan bahwa masing-masing ekstrak dari daun $B$. hirtella mempunyai kemampuan penghambatan yang berbeda-beda. Hal ini disebabkan oleh kandungan senyawa pada masing-masing ekstrak berbeda sesuai dengan tingkat kepolaran pelarut. Zona hambat pada $S$. aureus dari yang terbesar hingga terkecil yaitu ekstrak etil asetat, ekstrak air, ekstrak etanol dan ekstrak $n$-heksan. Sedangkan pada E. coli yaitu ekstrak etil asetat, ekstrak air, ekstrak $n$-heksan dan ekstrak etanol. Berbeda dengan $S$. aureus dan E. coli zona hambat pada C. albicans terbesar pada ekstrak etil asetat kemudian disusul dengan ekstrak $n$-heksan, ekstrak etanol dan ekstrak air yang disajikan pada Gambar 3.

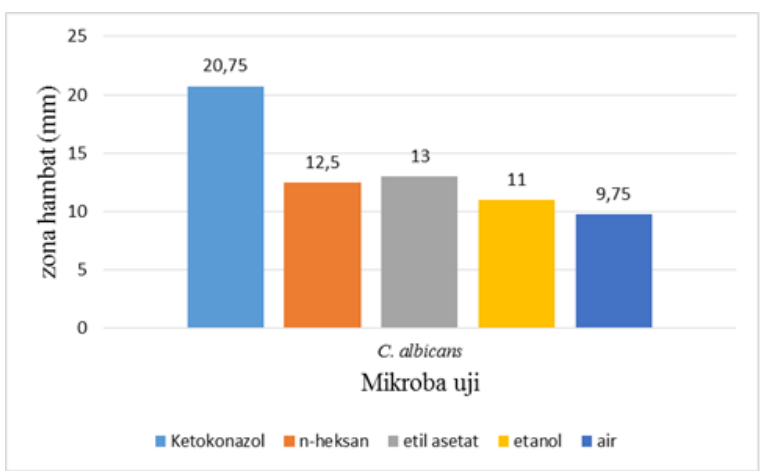

Gambar 3. Rata-rata zona hambat pada mikroba C. albicans dengan perlakuan ketokonazol, ekstrak $n$-heksan, etil asetat, etanol dan air

Diameter zona hambat yang terbentuk selanjutnya dianalisis menggunakan analisis ragam. Hasilnya menunjukkan bahwa masingmasing ekstrak berpengaruh terhadap mikroba uji dengan perbedaan yang nyata $(P<0,05)$. Selanjutnya dilakukan analisis lanjut menggunakan uji Duncan pada tingkat kepercayaan $95 \%$. Analisis lanjut dilakukan untuk mengetahui perbedaan pada masing-masing perlakuan. Hasil uji Duncan disajikan pada Tabel 1.

Tabel 1. Nilai rataan diameter zona hambat pada perlakuan variasi ekstrak

\begin{tabular}{|c|c|c|}
\hline No & Perlakuan & $\begin{array}{l}\text { Diameter zona } \\
\text { hambat }(\mathrm{mm})\end{array}$ \\
\hline 1. & $\mathrm{E} 1 \mathrm{~m}_{1}$ & $10,00 \pm 0,82 a b$ \\
\hline 2. & $E 2 m_{1}$ & $13,75 \pm 1,26 \mathrm{e}$ \\
\hline 3. & $E 3 m_{1}$ & $11,00 \pm 0,00 \mathrm{abc}$ \\
\hline 4. & $\mathrm{E} 4 \mathrm{~m}_{1}$ & $11,75 \pm 1,26 \mathrm{bcd}$ \\
\hline 5. & $\mathrm{E} 1 \mathrm{~m}_{2}$ & $10,50 \pm 0,58 a b$ \\
\hline 6. & $\mathrm{E} 2 \mathrm{~m}_{2}$ & $11,75 \pm 0,50 \mathrm{bcd}$ \\
\hline 7. & $E 3 m_{2}$ & $10,25 \pm 0,50 a b$ \\
\hline 8. & $\mathrm{E} 4 \mathrm{~m}_{2}$ & $10,75 \pm 2,36 a b c$ \\
\hline 9. & $\mathrm{E} 1 \mathrm{~m}_{3}$ & $12,50 \pm 1,29 \mathrm{cde}$ \\
\hline 10. & $E 2 m_{3}$ & $13,00 \pm 0,82 \mathrm{de}$ \\
\hline 11. & $\mathrm{E} 3 \mathrm{~m}_{3}$ & $11,00 \pm 1,82 \mathrm{abc}$ \\
\hline 12 & $\mathrm{E} 4 \mathrm{~m}_{3}$ & $9,75 \pm 0,96 a$ \\
\hline
\end{tabular}

Keterangan:

$\mathrm{E} 1=$ ekstrak $n$-heksan

$\mathrm{E} 2=$ ekstrak etil asetat

$\mathrm{E} 3=$ ekstrak etanol

$\mathrm{E} 4=$ ekstrak air

$\mathrm{m}_{1}=S$. aureus

$\mathrm{m}_{2}=$ E. coli

$\mathrm{m}_{3}=$ C. Albicans 
Hasil uji tersebut menunjukkan bahwa zona hambat terbesar adalah pada $S$. aureus yang diberi ekstrak etil asetat, dengan diameter ratarata zona hambat $13,75 \pm 1,26 \mathrm{~mm}$. Zona hambat terkecil ditunjukkan pada mikroba $C$. albicans pada ekstrak air dengan diameter rata-rata zona hambat 9,67 $\pm 0,82 \mathrm{~mm}$. Perbedaan zona hambat dapat disebabkan oleh struktur dinding sel pada mikroba uji berbeda-beda. Struktur dinding sel bakteri Gram positif lebih sederhana dibandingkan struktur dinding sel bakteri Gram negatif sehingga memudahkan senyawa antibakteri masuk ke dalam sel dan menemukan sasaran untuk bekerja. Irianto (2006) menyatakan bakteri Gram positif dinding selnya terdiri atas peptidoglikan, terdapat asam teikhoat. Bakteri Gram negatif terdiri atas tiga lapis yaitu lapisan dalam adalah peptidoglikan dan lapisan luar terdiri atas dua lapisan yaitu lipopolisakarida dan lipoprotein. $C$. albicans mempunyai zona hambat terkecil, karena termasuk organisme eukariotik yang susunan dinding selnya lebih kompleks dibandingkan dengan bakteri. Hasil tersebut juga didukung oleh pendapat Allison dan Gilbert (2004) dalam Efendi dan Hertiani (2013) perbedaan aktivitas terhadap beberapa mikroba disebabkan perbedaan struktur penyusun dinding sel mikroba. Dinding sel bakteri Gram negatif memiliki lapisan peptidoglikan yang lebih tipis dibandingkan bakteri Gram positif, tetapi memiliki lapisan membran luar tambahan yang lebih kompleks. Akibatnya, secara umum akan lebih sulit menembus dinding sel bakteri Gram negatif daripada Gram positif. Sedangkan struktur penyusun dinding sel $C$. albicans tersusun dari polisakarida (mannan, glukan, kitin), protein dan lipid dengan membran sel di bawahnya yang mengandung sterol.

Ekstrak etil asetat membentuk zona hambat terbesar karena etil asetat bersifat semipolar, sehingga senyawa non polar dan polar dapat larut dalam etil asetat. Etil asetat mengandung senyawa antimikroba yang mampu menghambat atau membunuh mikroba lebih tinggi dibandingkan ekstak yang lainnya. Fitrial et al. (2008) menyatakan senyawa semi polar mempunyai afinitas lebih tinggi untuk berinteraksi dengan diding sel, sehingga ekstrak semi polar lebih efektif menghambat pertumbuhan bakteri daripada ekstrak etanol, air (polar) dan ekstrak nheksan (non polar).

Berdasarkan uji fitokimia ekstrak etil asetat mengandung senyawa saponin. Saponin sebagai antibakteri dan antifungi menyebabkan kerusakan protein dan enzim di dalam sel. Saponin dapat berdifusi melalui membran luar dan dinding sel bakteri yang rentan kemudian mengikat membran sitoplasma sehingga mengganggu dan mengurangi kestabilan sel. Hal ini menyebabkan sitoplasma bocor keluar dari sel yang mengakibatkan kematian sel bakteri (Cavalieri,
2005 dalam Taufiq et al., 2015). Saponin bersifat sebagai surfaktan yang berbentuk polar akan menurunkan tegangan permukaan membran sterol dari dinding sel $C$. albicans, sehingga menyebabkan gangguan permeabilitas membran yang berakibat pemasukan bahan atau zat-zat yang diperlukan dapat terganggu akhirnya sel membengkak dan pecah (Luning et al., 2008 dalam Fitriani et al., 2013).

Selain mengandung saponin pada uji total fenolik, ekstrak etil asetat juga mengandung total senyawa fenolik sebanyak $23,530 \mathrm{ml} / \mathrm{g}$. Fenol berinteraksi dengan protein membentuk kompleks protein fenol. Ikatan antara protein dan fenol adalah ikatan yang lemah dan segera mengalami peruraian. Fenol yang bebas, akan berpenetrasi ke dalam sel bakteri, menyebabkan presipitasi dan denaturasi protein. Fenol dapat menyebabkan koagulasi protein sehingga membrane sel mengalami lisis (Juliantina et al., 2008). Senyawa fenol mengganggu dinding sel dan membran, mengendapkan protein dan menonaktifkan enzim-enzim (Katzung, 2001). Senyawa fenol dapat menghambat pertumbuhan bakteri dengan cara koagulasi protein dan lisis membran sel bakteri. Terjadinya lisis pada membran sel mengakibatkan kebocoran pada sel sehingga metabolit esensial yang dibutuhkan oleh mikroba keluar dari sel dan kemudian fenol di dalam sel akan merusak sistem kerja sel, merusak membran sitoplasma yang mengakibatkan terhambatnya pertumbuhan sel atau matinya sel, mendenaturasikan protein, asam-asam nukleat, menghambat sintesis asam nukleat dan protein (Novianti, 2015). Fenol mempunyai aktivitas antibakteri berspektrum luas terhadap bakteri Gram positif dan Gram negatif (Oliver et al., 2001). Mekanisme senyawa fenol sebagai antifungi yaitu berinteraksi dengan dinding sel fungi, dimana pada kadar yang rendah akan mendenaturasi protein dan pada kadar yang tinggi akan menyebabkan koagulasi protein sehingga sel akan mati (Siswandono dan Sukardjo,1995 dalam Lidyawita et al, 2013).

Total senyawa fenol pada ekstrak etil asetat lebih kecil bila dibandingkan ekstrak etanol, karena golongan senyawa fenolik pada daun $B$. hirtella lebih banyak yang bersifat polar. Meskipun kandungan total fenol ekstrak etil asetat lebih sedikit dibandingkan ekstrak etanol, akan tetapi ekstrak etil asetat ini mempunyai zona penghambatan terhadap mikroba uji lebih besar. Hal ini menunjukkan total senyawa fenol ini tidak sebanding dengan aktivitas antimikroba, karena ada senyawa-senyawa yang lain yang mempunyai aktivitas sebagai antimikroba pada ekstrak etil asetat salah satunya senyawa neophytadiene.

Neophytadiene merupakan golongan senyawa terpenoid. Terpenoid dapat menghambat pertumbuhan atau mematikan 
bakteri dengan mengganggu proses terbentuknya membran atau dinding sel, sehingga tidak terbentuk atau terbentuk tidak sempurna (Ajizah, 2004). Selain itu Cowan (1999) dalam Amalia et al. (2014) menyatakan bahwa terpenoid memiliki aktivitas antibakteri dengan mekanisme yaitu bereaksi dengan porin (protein transmembran) pada membran luar dinding sel bakteri membentuk ikatan polimer yang kuat sehingga mengakibatkan rusaknya porin. Rusaknya porin yang merupakan pintu keluar masuknya senyawa akan mengurangi permeabilitas dinding sel bakteri. Permeabilitas dinding sel ini akan mengganggu masuk keluarnya nutrisi dan senyawa lainnya, sehingga pertumbuhan bakteri terhambat atau mati. Sedangkan mekanisme kerja terpenoid sebagai antifungi menurut Ahmad dan Gholib (2013) yaitu karena senyawa terpenoid ini larut dalam lemak sehingga dapat menembus membran sel fungi dan mempengaruhi permeabilitasnya serta menimbulkan gangguan pada struktur dan fungsi membran sel.

Ekstrak etil asetat mempunyai zona hambat terbesar sehingga digunakan untuk uji selanjutnya yaitu uji variasi konsentrasi etil asetat, untuk mengetahui pengaruh variasi konsentrasi terhadap zona hambat yang terbentuk. Menurut Yunus et al (2014), variasi konsentrasi ini bertujuan untuk melihat perbedaan diameter hambat dari masing-masing konsentrasi yang digunakan. Uji awal variasi konsentrasi menggunakan variasi konsentrasi 1000 ppm, 500 ppm, $250 \mathrm{ppm}$ dan $125 \mathrm{ppm}$. Hasil uji tersebut diketahui zona hambat masih terbentuk pada konsentrasi 500 ppm, sedangkan pada

\section{Daftar Referensi}

Ahmad, R. Z Dan Gholib D. 2013. Pengujian Ekstrak Etanol, Etil asetat dan Minyak Atsiri Daun Beluntas (Pluchea indica (L) Lees.) terhadap Trichophyton mentagrophytes dan Cryptococcus neoformans Secara In Vitro. Balai Besar Penelitian Veteriner,Bogor.

Ajizah, A. 2004. Sensitivitas Salmonella typhimurium terhadap Ekstrak Daun Psidium Guajava L. Bioscientie. 1 (1): 31 38.

Amalia, S., S. Wahdaningsih dan N. K. Untari. 2014. Antibacterial Activity Testing of $\mathrm{N}$ Hexane Fraction of Red Dragon (Hylocereus polyrhizus Britton \& Rose) Fruit Peel on Staphylococcus aureus ATCC 25923. Trad. Med.J. 19 (2): 89-94.

Andarwulan, N. dan K. Shetty. 1999. Phenolic Content in Differential Tissue Culture of Trasf (Ormed and AgrobacteriumTransformed Roots af Anise Pimpinella konsentrasi 250 ppm dan 125 ppm tidak terbentuk zona hambat. Berdasarkan uji tersebut maka ditetapkan variasi konsentrasi ekstrak yang diujikan yaitu antara 500 ppm dan 250 ppm, untuk diketahui konsentrasi ekstrak minimal yang masih bisa menghambat mikroba uji. Variasi konsentrasi yang digunakan yaitu 500 ppm, 450 ppm, 400 ppm, 350 ppm, 300 ppm dan 250 ppm.

Hasil uji menunjukkan semakin besar konsentrasi ekstrak, semakin besar pula zona hambat yang terbentuk. Pada konsentrasi 300 ppm masih terbentuk zona hambat sedangkan pada konsentrasi 250 ppm tidak ada zona hambat yang terbentuk, sehingga konsentrasi terendah yang mampu menghambat mikroba uji adalah 300 ppm. Menurut Nurmahani et al. (2012) dalam Rakasiwi dan Soegiharjo (2014), KHM didefinisikan sebagai konsentrasi terendah ekstrak yang dapat menghambat pertumbuhan bakteri dalam waktu 24 jam inkubasi.

\section{Simpulan}

Berdasarkan hasil penelitian dapat disimpulkan bahwa (1). Jenis pelarut ekstrak daun $B$. hirtella yang mempunyai zona hambat terbaik adalah etil asetat pada bakteri S. aureus; (2). Konsentrasi minimal ekstrak etil asetat yang menunjukkan terbentuknya zona hambat adalah pada konsentrasi 300 ppm; dan (3). Kandungan senyawa tertinggi pada ekstrak $n$-heksan daun $B$. hirtella adalah stigmasterol, ekstrak etil asetat adalah neophytadiene, dan ekstrak etanol adalah ethyl palmitate.

anisum L.). Journal of Agriculture Food Chemists. 47: 1776-1780.

Darsana, I Gede O., I N. K. Besung dan H. Mahatmi. 2012. Potensi Daun Binahong (Anredera cordifolia (Tenore) Steenis) dalam Menghambat Pertumbuhan Bakteri Escherichia coli secara In Vitro. Indonesia Medicus Veterinus. 1 (3): $337-351$.

Davis, W.W. and Stout, T.R. 1971. Disc plate method of microbiological antibiotic assay. American Society for Microbiology, 22(4): 659-665

Efendi, Y. N. dan T. Hetiani. 2013. Potensi Antimikroba Ekstrak Etanol Sarang Semut (Myrmecodia tuberosa Jack) terhadap Candida albicans, Escherichia coli dan Staphylococcus aureus. Trad.Med.J. 18 (1): 53-58.

Fitrial, Y., M. Astawan, S. S. Soekarto, K. G. Wiryawan, T. Wresdiyati dan R. Khairina. 2008. Antibakteri Ekstrak Biji Teratai (Nymphaea pubescens Wild) terhadap Bakteri Patogen Penyebab Diare. Jurnal 
Teknologi dan Industri Pangan. 19 (2): 158164.

Fitriani, E., M. Alwi. dan Umrah. 2013. Studi Efektivitas Ekstrak Daun Sereh Wangi (Cymbopogon nardus L.) Sebagai Anti Fungi Candida albicans. Biocelebes.7 (2): $15-20$.

Harborne, J.B. 1987. Metode Fitokimia: Penuntun cara modern menganalisis tumbuhan. Penerbit ITB, Bandung.

Hartutiningsih, M. Siregar, R. S. Purwantoro, Sudarmono dan A. Agusta. 2009. Pengungkapan Potensi Obat pada Tiga Jenis Begonia Terpilih (B. muricata Blume, B. multangula Blume, B. "Bacem Kebo") melalui Uji Antibakteri Escherichia coli dan Staphylococcus aureus secara In Vitro. Prosiding Seminar Nasional Sains II,13-15 November, Bogor.

Himawan, H. C., V. Surjana dan L. Prawira. 2012. Karakterisasi dan Identifikasi Komponen Kimia Rimpang Kunyit (Curcuma domestica Val.) Sebagai Inhibitor Bakteri Patogen. Fitofarmaka. 2 (2): 30-39.

Indrakumar, I., R. Gomathi dan S. Karpagam. 2014. Antimicrobial and In vitro Antioxidant Potential of Begonia dipetala Graham. Int. J. Pharm. Sci. Rev. Res. 27 (2): 382-386.

Irianto, K. 2006. Mikrobiologi Menguak Dunia Mikroorganisme Jilid 1. Yrama Widya, Bandung.

Juliantina, F., D. A. Citra, B. Nirwani, T. Nurmasitoh dan E. T. Bowo. 2008. Manfaat Sirih merah (Piper crocatum) sebagai Agen Antibakterial terhadap Bakteri Gram positif dan Gram Negatif. Jurnal Kedokteran dan Kesehatan Indonesia. Universitas Islam Indonesia, Yogyakarta

Katzung, B. G. 2001. Farmakologi: Dasar dan Klinik. Diterjemahkan oleh Bagian Farmokologi UNAIR.2004, Salemba Medika, Jakarta.

Lidyawita, R., Sudarsono dan Harsini. 2013. Antifungal Activities of Boiled Cashew Bark (Anacardium occidentale L.) on C. albicans In Acrylic Resin. Trad. Med. J. 18(1):46-52.

Marliana, S. D., V. Suryanti dan Suyono. 2005. Skrining Fitokimia dan Analisis Kromatografi Lapis Tipis Komponen Kimia Buah Labu Siam (Sechium edule Jacq. Swartz.) dalam Ekstrak Etanol. Biofarmasi. 3 (1): 26-31.

Nagariya, A. K., A. K. Meena, D. Jain, B. P. Gupta, A. K Yadav, M. R. Gupta, A. K
Pathak dan Neelam. 2010. Medicinal Plants Used in the Healing of Skin Diseases in Different Regions of India: A Review. International Journal of Chemical and Analytical Science. 1 (5): 110-113.

Novianti, D. 2015. Kemampuan Daya Hambat Ekstrak Buah Mengkudu (Morinda citrifolia) terhadap Bakteri Shigella Dysenteriae. Sainmatika. 12 (1): 1-7.

Oliver, S. P., B. E. Gillespie, M. J. Lewis, S. J. Ivey, R. A. Almeida, D. A. Luther, D. L. Johnson, K. C. Lamar, H. D. Moorehead dan H. H. Dowlen. 2001. Efficacy of a New Premilking Teat Disinfectant Containing a Phenolic Combination for the Prevention of Mastitis. J. Dairy Sci. 84: 1545-1549.

Rafsanjani, M. K. dan W. D. R. Putri. 2015. Karakterisasi Ekstrak Kulit Jeruk Bali Menggunakan Metode Ultrasonic Bath (Kajian Perbedaan Pelarut dan Lama Ekstraksi. Jurnal Pangan dan Argoindustri. 3 (4): 1473-1480.

Rakasiwi, B. L. dan C. J. Soegihardjo. 2014. Uji Aktivitas Antibakteri Ekstrak Etanolik Daging Buah Buni (Antidesma bunius (L.) Spreng) terhadap Staphylococcus aureus ATCC 25922 dan Escherichia coli ATCC 25923. Jurnal Farmasi Sains dan Komunikasi. 11 (1): 23-31.

Sangi, M., Max R. J. Runtuwene1, H. E. I. Simbala dan V. M. A. Makang. 2008. Analisis Fitokimia Tumbuhan Obat di Kabupaten Minahasa Utara. Chem. Prog. 1 (1): 47-53.

Taufiq, S., U. Yuniarni dan S. Hazar. 2015. Uji Aktivitas Antibakteri Ekstrak Etanol Biji Buah Pepaya ( Carica papaya L.) terhadap Escherichia coli dan Salmonella thypi. Prosiding Penelitian SPeSIA, Unisba.

Widyawati, P. S., C. H. Wijaya, P. S. Harjosworo dan D. Sajuthi. 2010. Pengaruh Ekstraksi dan Fraksinasi terhadap Kemampuan Menangkap Radikal Bebas DPPH (1,1Difenil-2- Pikrilhidrazil) Ekstrak dan Fraksi Daun Beluntas (Pluchea indica Less). Seminar Rekayasa Kimia dan Proses 2010. Universitas Diponegoro, Semarang.

Yunus, R. A. H. Alimuddin dan P. Ardiningsih. 2014. Uji Aktivitas Antibakteri Ekstrak Kulit Buah Tampoi (Baccaurea macrocarpa) terhadap Bakteri Escherichia coli dan Staphylococcus aureus. JKK. 3 (3): 19- 24. 